ситуацією слід розуміти діалогічну та рольову (ігрову) взаємодію всіх їі учасників на основі професійного контексту. Отже, тріада «задача - діалог - гра» утворює базовий технологічний комплекс, який створює ціннісно-смислове поле міжсуб'єктного спілкування в особистісно зорієнтованому процесі [1]. Такий підхід забезпечує ситуацію, що сприяє готовності студента до творчої професійної діяльності загалом і формуванню загальнокультурної компетентності студента у процесі вивчення психолого-педагогічних дисциплін зокрема.

У процесі професійної підготовки формуються і розвиваються складники загальнокультурної компетентності фахівця, які надають йому змогу максимально реалізувати свій інтелектуальнотворчій потенціал; застосовувати методи самовиховання і самореалізації, зорієнтовані на систему індивідуальних, національних і загальнолюдських цінностей. Організація інтерактивного навчання у процесі вивчення психолого-педагогічних дисциплін сприяє розвитку соціальнорольових здібностей студентів, що надає змогу майбутнім учителям застосовувати засоби та технології інтеркультурної взаємодії; розробляти і реалізовувати стратегії діяльності, поведінки й кар'єри в умовах міжкультурного суспільства; інтерактивно опановувати та створювати моделі толерантної поведінки й конструктивної діяльності в умовах культурних, мовних, релігійних та інших відмінностей між народами. Отже, організація інтерактивного навчання у процесі вивчення психолого-педагогічних дисциплін допомагає студентам активно включатися до сучасного освітнього та соціального простору, сприяє їхній професійній i соціальній адаптації, ефективному формуванню загальнокультурної компетентності, що безпосередньо пов'язане 3 міжнародними процесами: наближенням вітчизняної освіти до європейської у межах Болонського процесу, глобалізацією та інтернаціоналізацією культурного та інформаційного світового простору.

\title{
Література
}

1. Ананьев Б. Г. Человек как предмет познания / Борис Герасимович Ананьев. - [3-е изд.]. - СПб : Питер, 2001. - 288 с. 2. Выготский Л. С. Собрание сочинений: в 6 т. / Л. С. Выготский ; [гл. ред. А. В. Запорожец]. - Т. 2 : Проблемы общей психологии. - М. : Педагогика, 1982. -504 с. 3. Лернер И. Я. Состав содержания образования и пути его воплощения в учебнике / И. Я. Лернер // Проблемы школьного учебника. - М. : Просвещение, 1978. - Вып. 6. - С. 63-82. 4. Малихін О. В. Методика викладання у вищій школі: [навч. посіб.] / [ авт.-укл. О. В. Малихін, І. Г. Павленко, О. О. Лаврентьєва, Г. І. Матукова ]. - Сімферополь : ДІАЙПІ, 2011. - 224 с. 5. Малихін О. В. Організація самостійної навчальної діяльності студентів вищих педагогічних навчальних закладів: теоретико-методологічний аспект: [монографія] / О. В. Малихін. - Кривий Ріг : Видавничий дім, 2009. - 307 с. 6. Матюшкин А. М. Проблемные ситуации в мышлении и обучении / Алексей Михайлович Матюшкин. - М. : Педагогика, 1978. - 208 с. 7. Махмутов М. И. Организация проблемного обучения в школе: [кн. для учит.] / Мирза Исмаилович Махмутов. - М. : Просвещение, 1977. - 240 с. 8. Леонтьев А. Н. Деятельность. Сознание. Личность / Алексей Николаевич Леонтьев. - М. : Политиздат, 1977. - 304 с. 9. Селевко Г. К. Современные образовательные технологии: [учеб. пособ.] / Герман Константинович Селевко. - М. : Народное образование, 1998. - 256 с. 10. Эльконин Д. Б. Психология игры / Даниил Борисович Эльконин. - М. : Педагогика, 1978. - 304 с.

Тетяна Мішеніна

\section{ТЕХНОЛОГІЧНИЙ ПІДХІД ДО НАВЧАННЯ У ПРОЦЕСІ ФОРМУВАННЯ ДИДАКТИЧНОЇ КОМПЕТЕНТНОСТІ МАЙБУТНЬОГО ВЧИТЕЛЯ ФІЛОЛОГІЧНИХ СПЕЦАЛЬНОСТЕЙ}

Мішеніна Т. М. Технологічний підхід до навчання у процесі формування дидактичної компетентності майбутнього вчителя філологічних спеціальностей.

У статті розкрито сутність технологічного підходу до навчання у процесі формування дидактичної компетентності майбутнього вчителя філологічних спеціальностей. Розкрито сутнісні характеристики дидактичних категорій: зміст освіти, рівні засвоєння освіти, навчальні ситуації, навчальні завдання. 3 урахуванням опису цілей навчання, видів змісту освіти й рівнів засвоєння подано грунтовний перелік можливих поєднань цілей і видів змісту освіти.

Ключові слова: технологічний підхід, технолого-конструювальна діяльність учителя, дидактична компетентність, майбутні вчителі філологічних спеціальностей. 
Мишенина Т. М. Технологический поход к обучению в процессе формирования дидактической компетентности будущого учителя филологических специальностей.

В статье раскрыта сущность технологического подхода к обучению в процессе формирования дидактической компетентности будущего учителя филологических специальностей. Раскрыты сущностные характеристики дидактических категорий: содержание образования, уровни усвоения образования, учебные ситуации, учебные задания. С учетом описания целей обучения, видов содержания образования и уровней усвоения приведен исчерпывающий список возможных комбинаторных соединений целей и видов содержания образования.

Ключевые слова: технологический подход, технолого-конструирующая деятельность учителя, дидактическая компетентность, будущие учителя филологических специальностей.

Mishenina T. M. Technological approach to training in forming pedagogical competence of future teachers philological specialties.

The article reveals the essence of the technological approach to learning in the process of didactic competence of future teachers of philological specialties. Disclosed the essential characteristics of didactic categories: educational content, the levels of assimilation of education, training situation, the learning activities. Given the description of the learning objectives, the types of educational content and levels of assimilation is an exhaustive list of possible targets and compounds of combinatorial types of educational content.

Key words: technological approach, technological and constructive activity teachers, teaching competence, future teachers philological specialties.

Організація навчання становить процес, що передбачає побудову, конструювання, синтезування об'єкта (у нашому випадку процесу навчання) - на відміну від аналізу об'єкта, розкладання його на складники. У дослідженнях, присвячених технолого-конструювальній діяльності вчителя, на першому плані постає процес конструювання (що лежить в основі організації навчання), який має бути вивчений у всіх його виявах і закономірностях.

Під «конструюванням» у дидактичному значенні розуміємо процес розроблення вчителем дидактичної моделі сценарію майбутнього навчального процесу (уроку). Наведена дефініція $\epsilon$ найбільш загальною, зорієнтованою на загальну характеристику й інтерпретацію результату, процес конструювання. Більш конкретне визначення конструювання припускає виокремлення його процесуальних компонентів, які в узагальненому плані називаються процедурами.

Отже, конструювання становить сукупність і послідовність процедур, у результаті здійснення яких здійснюється розроблення вчителем дидактичної моделі сценарію навчального процесу (уроку).

У педагогічних розвідках конструювання навчального процесу (уроку) стали підніматися і розроблятися переважно в напрямку дослідження творчої діяльності вчителя (В. Загвязинський, П. Кан-Калик, В. Краєвський, Ю. Львова, Н. Нікандров, Р. Скульський, В. Сластьонін та інші). Механізм здійснення творчої діяльності розуміється як низка процедур, більшість із яких мають безпосередній стосунок до конструювання сценарію уроку.

Mema cmammi - розкрити сутнісні характеристики дидактичних категорій у межах технологічного підходу у процесі формування дидактичної компетентності майбутніх учителів філологічних спеціальностей.

Аналіз змісту процедури творчої діяльності передбачає звернення особливої уваги на їх принципову відмінність від процедур суворо алгоритмічного характеру: творча діяльність передбачає прийняття оригінального, нестандартного рішення, здійснення вибору необхідного варіанту або способу розв'язання з безлічі можливих; вона «не зводиться до чітко окресленої поопераційної технології, а передбачає необхідність оцінки нескінченного розмаїття ситуацій, опори на здогад й інтуїцію» [1, с. 73].

Водночас процедури творчої діяльності не $є$ кореляційними, оскільки їх неможливо вибудувати за лінійним принципом; натомість вони можуть поєднуватися, здійснюватися паралельно, повторюватися, мати перетинання на рівні ядра й периферії.

Отже, технологічний підхід до навчання майбутніх учителів філологічних спеціальностей перебуває в тісному взаємозв'язку з розробленням процедур конструювання сценарію уроку, 
які мають творчий характер. Наведене твердження характеризує процесуальний аспект конструювання. Важливе значення для розкриття процесу конструювання має також його змістовий аспект.

Якщо процесуальний аспект визначає процедурний перебіг процесу конструювання в цілому, тобто загальні риси структури окресленого процесу, то змістовий аспект визначає специфіку кожної окремо взятої процедури, іiі особливі риси, що залежать від наповнення кожної процедури своїм специфічним змістом. Визначимо специфіку процесу конструювання 3 позиції дидактики.

Специфіка конструювання навчального процесу безпосередньо пов'язана зі специфікою дидактики як навчальної дисципліни. Вітчизняна дидактика склалася як категоріально навчальна дисципліна, тобто як дисципліна, що вивчає і розкриває базисні дидактичні категорії, що корелюють із однойменним основним елементом навчання. Вивчення дидактики як педагогічного знання про сукупність дидактичних категорій сприяє ефективному пізнанню сукупності основних елементів навчання: мета навчання, зміст освіти, методи навчання, форми організації навчання, процес навчання. Виокремлені елементи визначають спрямувальний характер процедур, що утворюють процес конструювання (до процедур конструювання можна віднести визначення цілей уроку (цілепокладання), відбір і композицію навчального змісту, вибір методів навчання тощо).

Виокремлення більш складних процедур передбачає сукупність основних елементів навчання; поєднання інтелектуальної і практичної діяльності вчителя. До таких комплексних процедур відносимо прогнозування, проектування, планування тощо.

Ураховуючи сказане, розглянемо різні позиції, що стосуються конструювання навчального процесу (уроку). Вихідною можна вважати позицію Н. Кузьміної, яка пропонує визначення конструктивної діяльності вчителя, виражене через складники конструювання. «Конструктивна діяльність вчителя - це діяльність, пов'язана 3 відбором, композицією, проектуванням навчально-виховного матеріалу, створенням планів, тобто підгрунтя, на якому будується організаторська і комунікативна діяльність вчителя» [5, с. 82]. У цьому визначенні автор робить спробу розчленувати конструювання на частини, виявити складники процесу, якими $\epsilon$ «відбір», «композиція» і «проектування». Згідно 3 визначенням, всі ці процедури застосовуються до елемента навчання - навчально-виховного змісту. Процедурами визначено складник - «створення плану», представлений поза зв'язком з іншими елементами навчання.

Організація навчально-виховного процесу загалом і кожного уроку «починається 3 ïх планування, тобто з проектувальної, конструктивної діяльності вчителя» [5, с. 82]. Якщо в першому випадку автор розглядає «проектування» $\mathrm{i}$ «планування» $\mathrm{i}$ характеристики процедур, що створюють процес конструювання, то в іншому - найбільш загальним поняттям $\epsilon$ «планування». При цьому поняття «проектування» і «конструювання», по-перше, є часткові, використовувані під час опису процесу планування i, по-друге, вживаються як синоніми.

Ідентичність понять «конструювання» $\mathrm{i}$ «проектування» виявляється під час грунтовного аналізу Н. Кузьміної складу технолого-конструювальної діяльності. «Технолого-конструктуювальна діяльність учителя передбачає зміст проектування: 1) зміст майбутньої діяльності; 2) системи і послідовності власних дій; 3) системи і послідовності дій учнів» [5, с. 83].

Якщо у визначенні «конструювання» проектуванню підлягає лише навчально-виховний зміст, то в останньому випадку, під час опису змісту конструювання, проектування представлено більш широко: воно стосується не тільки змісту, а й обох діяльностей - учителя й учнів.

Отже, поняття «конструювання» в сучасній педагогічній думці окреслюється дослідженнями структури діяльності вчителя. Виокремлюються складники процесу конструювання, його процедури. Процедури мають комплексний характер, зумовлений взаємозв'язком елементів навчання з діяльністю вчителя. Відповідні цим термінам процеси починають більш глибоко досліджуватися іншими авторами.

Одним 3 основних напрямків, у якому конструювання використовується як складник творчої діяльності вчителя, $є$ задачний підхід. Ідеться про таку організацію навчального процесу навчання майбутніх учителів філологічних спеціальностей, згідно з якою творча діяльність учителя розглядається як постановка і розв'язання педагогічного завдання. Найбільш грунтовно таку позицію представлено в переліку загальних правил евристичного пошуку, запропонованого В. Сластьоніним. До переліку вноситься сукупність таких процедур: 
«аналіз педагогічної ситуації (діагноз); проектування результату в зіставленні з вихідними даними (прогноз); аналіз засобів, придатних для перевірки припущення та досягання результату; конструювання і реалізація навчально-виховного процесу; оцінка отриманих даних; формулювання нових завдань» [8, с. 68].

Викладений перелік охоплює низку процедур, що входять до складу конструювання (згідно 3 нашим визначенням). Це «аналіз ситуації», «проектування», «прогнозування». Процедури «проектування», «прогнозування» представлені в єдності й тотожності. Наведений ряд передбачає власне «конструювання», відокремлене від процедур проектування та прогнозування, однолінійне 3 ними, водночас таке, що має спільну семантику із процедурою «реалізація навчально-виховного процесу». Така позиція передбачає розуміння конструювання не як цілісного етапу підготовки вчителя до уроку, завершальним етапом якого є розроблення відповідного сценарію навчального процесу, а як відтворення навчального процесу в ході самого уроку.

Аналогічної позиції з приводу конструювання дотримується і В. Краєвський, який уважає конструювальну діяльність однієї з найважливіших у педагогічній творчості вчителя, за створення незліченної безлічі різних конкретних ситуацій у навчанні [2, с. 289]. Водночас автор розглядає «проектування» як процес розроблення навчальних планів, програм, підручників, інших навчальних матеріалів, складників «нормативний сценарій» навчання, яким учитель повинен скористатися за побудови конкретного навчального процесу.

Представниками задачного підходу є також В. Кан-Калик, М. Нікандров, які пропонують авторську модель розв'язання педагогічного завдання. Науковці підкреслюють, що процес розв'язання педагогічної задачі розпочинається з усвідомлення виниклої проблеми. Причому одночасно або послідовно можуть осмислюватися різні педагогічні завдання. Це може бути спільним завданням усієї діяльності вчителя. Може бути також запропонованим педагогічне завдання, пов'язане 3 конкретним етапом педагогічної діяльності. У кожному мікроелементі педагогічного процесу виникає ситуативне педагогічне завдання. Далі послідовно виокремлюються такі фази розв'язання педагогічного завдання, як аналіз вихідних даних, висунення гіпотези, визначення системи методів педагогічних взаємодій. Після окреслених етапів учитель розв'язує комунікативні завдання, тобто планує педагогічне спілкування з учнями [2, с. 28-30].

Якщо модель розв'язання педагогічного завдання спроектувати на процес конструювання дидактичної моделі уроку, то констатуємо певну кількість фаз розв'язання педагогічної завдання, що можуть бути представленими як процедури процесу конструювання («аналіз вихідних даних», «висунення гіпотези» і «визначення системи методів педагогічних взаємодій»). Виокремлені процедури достатньо неоднорідні: одні 3 них (перша і друга) відносяться до складних комплексних процедур; інші (третя) відносяться до процедур змістового характеру. Крім цього, назва першої процедури характеризує певний процес; назва другої і третьої процедур відображає досягнення певного результату. На наше переконання, найбільш перспективно відображати в назві комплексних процедур їх процесуальний характер (наприклад, проектування, планування тощо), оскільки у їх сутності закладено діяльнісний компонент виконавця. У зв'язку з цим процедуру «висунення гіпотези» дефініційно визначаємо як «прогнозування».

Задачний підхід може бути використаний не тільки стосовно аналізу і розгляду цілісного процесу конструюваня певної сукупності його ланок; дослідження окремих ланок процесу. Зокрема, Г. Муравйова пропонує розглядати процедуру проектування як дидактичне завдання i розробляє спосіб його розв'язання за аналогією з інженерним проектуванням [7, с. 34]. Ми поділяємо думку науковця і розглядаємо дидактичне проектування як вид професійної педагогічної діяльності, який становить розроблення проекту технології навчання на певному його відрізку. Проект є дидактичним описом навчально-пізнавальної діяльності учнів і засобів, необхідних для іiї реалізації. У процесі проектування навчання вихідною є технологія, тобто система дій учнів, продуктом яких є зміни в особистісному утворенні учнів. Абсолютно виправданим можна вважати думку науковця про необхідність розроблення дидактичного опису проектованої діяльності учнів у навчальному процесі. Цей процес аспектуально розроблений у дидактиці. Можна також акцентувати увагу на цьому описі як найважливішого складника технології. Водночас нам уявляється слушною позиція, яка полягає в тому, що технологія й опис діяльності учнів не $є$ рівнозначними. Технологія $є$ ширшою й загальною категорією, яка передбачає цілісне відображення всіх основних елементів навчального процесу і насамперед двох (а не однісї) діяльностей - учителя та учнів. 
Отже, концепція наукової організації педагогічної праці може служити основою розроблення питань технолого-конструювальної діяльності, яка розуміється в широкому значенні. Дидактичні умови допускають внесення до планування процедури конструювання, які можуть бути як змістовими, так і такими, що мають складний комплексний характер.

Напрямком дослідження технолого-конструювальної діяльності вчителя, що мають витоками практику роботи школи, уважаємо дидактико-методичний підхід, пов'язаний 3 описом конкретного досвіду роботи вчителів і дидактичним його осмисленням.

Педагог-практик Ю. Львова на матеріалі численних фрагментів уроків із гуманітарних дисциплін обгрунтовує найбільш загальні моменти в діяльності вчителя і намагається розробити модель цієї діяльності. Науковець фактично виокремлює два етапи в діяльності вчителя $з$ підготовки до уроку: формулювання змісту задуму уроку і розроблення задуму конкретного уроку, який складається з таких елементів: а) осмислення навчального матеріалу, встановленого чинною програмою; б) співвідношення навчального матеріалу із завданнями виховання та розвитку, з рівнем розвитку учнів цього року навчання; в) співвідношення 3 власним духовним станом, професійним і життєвим досвідом; г) співвідношення навчального матеріалу з конкретним класом і психологією окремих учнів [6, с. 12].

Формування змісту задуму уроку містить чотири елементи, виокремлені емпіричним шляхом з аналізу конкретних уроків із гуманітарних дисциплін і вбирають у себе те загальне, що $є$ характерним для формування задуму багатьох уроків. Виокремлені елементи є достатньо загальними, що вказують на стратегічний аспект діяльності вчителя; $\epsilon$ зіставними 3 конкретними діями вчителя, а отже, не $є$ технологічними. Іншими словами, учитель, використовуючи сукупність елементів і прикладів, має змогу самостійно розробити комплекс процедур задля навчання формувати свій власний задум уроку. Щоб формування задуму зробити технологічним, необхідно не тільки виокремити той чи інший набір елементів задуму уроку, але й указати сукупність найбільш загальних (дидактичних) процедур, які будуть доступними вчителю будь-якої спеціалізації.

Навчальні ситуації відповідно до функцій поділяються на однорідні і неоднорідні. Однорідні ситуації відносяться до однієї ланки навчального процесу, неоднорідні - до різних ланок [1, с. 197].

Залежно від підходів до організації процесу навчання О. Бударний виокремлює три види навчальних ситуацій відповідно до критерію джерела знань, сутності взаємодії з джерелом, контролю обсягу, узгодження й темпу вивчення навчального матеріалу:

1. Навчальні ситуації першого виду - ті, де джерелом знань є вчитель, і тому тільки він безпосередньо контролює обсяг, узгодження й темп подання навчального матеріалу; учні здійснюють переважно внутрішні дії (слухають, дивляться тощо). Учитель може говорити, показувати різні об'єкти, демонструвати досліди, звертатися до одного учня, до групи або фронтально (до всього класу) [1, с. 199].

2. У навчальних ситуаціях другого виду самі учні безпосередньо контролюють зміст досліджуваного матеріалу, не спостерігається зовнішньої взаємодії між ними і вчителем. Учитель функційно передає учням право регулювати обсяг, узгодження й темп вивчення навчального матеріалу. У ситуаціях цього вид учні отримують інформацію з будь-яких джерел, окрім учителя. При цьому можуть бути використані такі способи реалізації, як самостійна робота $з$ підручником та іншими посібниками, самостійні спостереження, усні, письмові, лабораторні та практичні роботи [1, с. 199-200].

3. Навчальні ситуації третього виду характеризуються тим, що у процесі подання і контролю змісту беруть участь кооперативно як учитель, так і учні. Обов'язковою має бути зовнішня взаємодія між учителем і учнями на основі обміну інформацією, інакше навчальна ситуація не буде віднесеною до такого виду. Характерним прикладом ситуацій цього виду є ситуації, у яких учитель задає учням питання і вислуховує відповіді, веде бесіду, дискусію [1, с. 200].

Подані вище види навчальних ситуацій, узяті за принципом окремішності або в певних, методично доцільних, поєднаннях, складають основу уроку.

Отже, технологічними характеристиками процесу навчання будемо вважати певні його структурні компоненти, а також уроки. Окреслимо взаємозв'язок - зміст освіти і його характеристики, що розширить наше уявлення про системоутворювальну роль навчальних ситуацій. 
Подамо короткий опис змісту освіти за І. Лернером і М. Скаткіним [2, с. 102-108; 3]. Насамперед виокремимо основні елементи змісту - знання, способи діяльності (вміння і навички), досвід творчої діяльності, досвід емоційно-ціннісного ставлення до світу. Кожен із зазначених елементів виявляється через певні види й ознаки. Види й ознаки конкретні і саме вони корелюють із конкретним навчальним матеріалом: 1. Види знань: Поняття і терміни; Факти дійсності і науки; Закони науки і дійсності; Теорії; Знання про способи діяльності; Знання про методи пізнання; Оцінні знання. 2. Види способів діяльності: Інтелектуальні (аналіз, синтез, абстрагування, конкретизація, узагальнення тощо); Практичні (конструкторські, трудові тощо); Предметні (робота з картою, з вимірювальними приладами); Загальнонавчальні (робота 3 книгою, складання плану, самоконтроль тощо). 3. Ознаки творчої діяльності: Самостійне перенесення знань і умінь у нову, що незнайому ситуацію; Бачення нової проблеми в знайомій ситуації; Бачення нової функції об'єкта; Самостійне комбінування відомих способів діяльності в новий; Бачення структури об'єкта; Бачення можливих рішень даної проблеми; Побудова нового способу розв'язання проблеми, відмінного від відомих.

Особливої уваги потребує розроблення творчих завдань, що враховують ознаки творчої діяльності. Слід зауважити, що нині не розроблено ще грунтовної системи, орієнтованої на цілеспрямоване формування творчої діяльності учнів.

Зміст освіти перебуває в тісному взаємозв'язку з рівнями засвоєння його елементів. Згідно 3 моделлю, описаною І. Лернером, засвоєння знань і способів діяльності відбувається на трьох рівнях: 1. Усвідомленого сприйняття й запам'ятовування, коли використовуваний зразок виокремлюється як безвідносний елемент. 2. Перенесення зразка в різні знайомі ситуації. 3. Творчого використання знань і способів діяльності, коли здійснюється їх перенесення в нові, раніше учневі не знайомі ситуації [2, с. 192; 3].

3 урахуванням опису цілей навчання, видів змісту освіти й рівнів засвоєння можливими $\epsilon$ різні поєднання цілей і видів змісту освіти. Використовуючи підходи, запропоновані М. Кларіним [4, с. 22-24], спробуємо викласти можливі поєднання у вигляді переліку конкретизованих таксономічних категорій:

1.0 Знання. 1.1 Володіння поняттями і термінами. 1.2 Знання фактів дійсності і науки. 1.3 Знання законів науки і дійсності. 1.4 Знання теорії. 1.5 Знання про способи діяльності. 1.6 Знання про методи пізнання.1.7 Знання про критерії оцінки.

2.0 Розуміння. 2.1 Розуміння фактів, правил і принципів. 2.2 Інтерпретація словесного матеріалу. 2.3 Інтерпретація схем, графіків, діаграм. 2.4 Перетворення словесного матеріалу в математичний вираз (переклад 3 однієї «мови» на іншу). 2.5 Передбачення наслідків, результатів. 2.6. Рефлексія наслідків і результатів.

3.0 Застосування. 3.1 Демонстрація правильного застосування методу, правила, закону, принципу, поняття, теорії, процедури. 3.2 Застосування правил, методів, понять тощо у знайомих ситуаціях. 3.3 Використання видів знань у нових ситуаціях.

4.0 Аналіз. 4.1 Аналіз елементів. 4.2 Аналіз відношень між елементами. 4.3 Аналіз принципів організації цілого. 4.4. Аналіз підходів до організації цілого.

5.0 Синтез. 5.1 Створення власного твору. 5.2 Розроблення плану дій. 5.3 Створення образу цілого на основі часткових даних. 5.4. Створення наукової картини на основі досягнень у певній галузі знань.

6.0 Оцінка. 6.1 Оцінка матеріалу і методів на основі внутрішніх критеріїв. 6.2 Оцінка матеріалу і методів на основі зовнішніх критеріїв.

Цілі навчання можна розділити на дві групи: таксономічні (категоріальні) і змістові. Таксономічні (категоріальні) цілі пов'язані з тією чи іншою таксономією цілей. У контексті нашого дослідження йдеться насамперед про знання, розуміння, застосування, аналіз, синтез і оцінку. Змістові цілі пов'язані з вивченням конкретного навчального предмета.

Змістова мета формулюється так, щоб становила установку на досягнення певного заданого результату. Ця установка водночас відповідає певним ознакам, за якими можна висновувати про досягнення тієї чи тієї категоріальної мети. Наприклад, змістова мета «назвати граматичні характеристики іменних частин мови» передбачає пригадування і відтворення відповідних відомостей, що, у свою чергу, характеризує категоріальну мету «знання». Отже, категоріальні і змістові цілі є взаємопов'язаними; їх співвідношення можна спостерігати у процесі побудови цільової моделі будь-якої теми з конкретного навчального предмета. 
Кожна змістова мета сформульована на основі добору дієслів неозначеної форми, що характеризує деяку зовні виражену спостережувану дію, що зумовлює певний, упізнаваний результат. До таких дісслів, зокрема, можна віднести: «записати», «назвати», «розрахувати» та інші.

Наведемо приблизний перелік дієслів, з використанням яких слід формулювати необхідні змістові цілі у процесі навчання гуманітарних предметів: відтворити, вибрати, виділити, висловити, обчислити, записати, зобразити, інтерпретувати, використати, модифікувати, назвати, пояснити, узагальнити, позначити, впізнати, охарактеризувати, оцінити, перегрупувати, перевести, переказати, перерахувати, перебудувати, повторити, підрахувати, передбачити, перетворити, застосувати, проаналізувати, розрахувати, реорганізувати, систематизувати, скласти, сформулювати, спростити, уточнити тощо.

Використання наведених (і подібних) дієслів дозволить навчити майбутнього вчителя чітко формулювати змістові цілі в процесі розроблення сценаріїв уроків.

Окреслюваний технологічний підхід до навчання майбутніх учителів філологічних спеціальностей передбачає грунтовний розгляд змісту навчальних завдань i їх характеристику. Навчальне завдання - складна і багатопланова дидактична категорія, що формально становить єдність певних приписів (настанов) і вказівок на об'єкт, щодо якого має місце певний припис.

Припис (настанова) пов'язаний із певною метою навчання і відображає іiі. У цьому сенсі навчальне завдання становить максимально конкретизовану сукупність цілей навчання. Вказівка на об'єкт, щодо якого має місце припис (настанова), відображає фрагмент змісту освіти, підлягає засвоєнню. Розрізняють завдання в навчальному матеріалі і в навчальному процесі. У навчальному матеріалі ми оперуємо насамперед із різними видами навчальних завдань - завданнями і вправами, які становлять частину навчального матеріалу. Крім завдань, у навчальному матеріалі використовуваними ще й тексти, що містять інформацію про досліджувані явища. У навчальному процесі весь навчальний матеріал - тексти, а також завдання і вправи - втілюється у форму навчальних завдань. Тому в співвідношенні зі змістом освіти у процесі навчання навчальне завдання $є$ форма втілення. Виконуючи навчальне завдання, учень розформовує зміст, закладений у завданні, і своєю діяльністю переводить цей зміст у нову форму - свідомість, тобто засвоює навчальний матеріал. У змістовно-логічних зв'язках між приписом (настановою) і вказівкою на об'єкт закладено спосіб виконання навчального завдання (спосіб вирішення задачі).

Виокремлення видів пов'язане з питаннями класифікації навчальних завдань. Класифікація це долінійне впорядкування навчальних завдань, яке пов'язує цілі навчання з можливими різними способами їх реалізації в навчальному процесі. Способом реалізації мети $\epsilon$ навчальне завдання як вид, що належить тій чи іншій класифікації. Наприклад, щоб організувати досягнення певної мети навчання, необхідно використовувати такі види навчальних завдань, як класні і позакласні, усні й письмові, репродуктивні і творчі тощо. У процесі добору видів навчальних завдань «під реалізацію» певної мети вони наповнюються конкретним предметним змістом і вносяться потім до лінійної структури навчального матеріалу.

Наведемо нижче приблизний перелік різних видів навчальних завдань, за допомогою яких можна обслуговувати різні цілі навчання (без вказівки на приналежність до тієї чи іншої класифікації).

Завдання: на знаходження шуканого, конструювання, доказ, 3 необхідними даними, надлишковими даними, недостатніми даними, репродуктивні, творчі, предметні, наочно-графічні, знаково-символічні, усні, письмові, попередні, основні, пропедевтичні, увідні, пробні, класні, домашні, тренувальні, перевірочні, контрольні, додаткові, допоміжні, на опис, на пояснення, на припис, на сприйняття, на розуміння, на застосування, мовні, передмовленнєві, некомунікативні, комунікативні, для фронтальної роботи, для групової роботи, для індивідуальної роботи тощо.

Нами розглянуто основні дидактичні категорії в технолого-конструювальному аспекті. При цьому виокремлено їх практично використовувані характеристики - види, ознаки, акти, ланки; вихідні елементи, які необхідно засвоїти майбутньому вчителю філологічних спеціальностей задля оволодіння процесом конструювання навчання, що інтенсифікує формування дидактичної компетентності майбутніх фахівців. Конструювання процесу навчання майбутнім учителем філологічних спеціальностей становить вихідний етап кваліфікованого здійснення навчання.

Перспективою подальших досліджень є дослідження реалізації розглянутих дидактичних категорій у процесі дидактичної підготовки майбутнього вчителя. Практична частина охоплює два основні питання: аналіз процесу навчання і його конструювання. 


\section{Література}

1. Дидактика средней школы / под ред. М. А. Данилова, М. Н. Скаткина. - М. : Просвещение, 1975. - 303 с. 2. Дидактика средней школы / под ред. М. Н. Скаткина. - [2-е изд.]. - М. : Просвещение, 1982. - 319 с. З. Загвязинский В. И. Педагогическое творчество учителя / В. И. Загвязинский. - М. : Педагогика, 1987. - 160 с. 4. Кларин М. В. Педагогическая технология в учебном процессе: Анализ зарубежного опыта / М. В. Кларин. - М. : Знание, 1989. - 80 с. 5. Кузьмина Н. В. Очерки психологии труда учителя / Н. В. Кузьмина. - Л. : Изд-во ЛГУ, 1967. 183 с. 6. Львова Ю. Л. Как рождается урок / Ю. Л. Львова. - М. : Знание, 1976. - 62 с. 7. Муравьева Г. Е. Подготовка студентов педвузов к проектированию процесса обучения на уроке: дис. ... канд. пед. наук / Г. Е. Муравьева. - М., 1990. - 175 с. 8. Сластенин В. А. Формирование личности учителя советской школы в процессе профессиональной подготовки / В. А. Сластенин. - М. : Просвещение, 1976. - 160 с.

Людмила Насілєнко

\section{ПЕДАГОГІЧНІ УМОВИ ФОРМУВАННЯ КОМУНІКАТИВНОЇ КОМПЕТЕНТНОСТІ МАЙБУТНІХ ЮРИСТІВ У ПРОЦЕСІ ВИВЧЕННЯ СПЕЦІАЛЬНИХ ДИСЦИПЛІН}

Насілєнко Л. А. Педагогічні умови формування комунікативної компетентності майбутніх юристів у процесі вивчення спеціальних дисциплін.

У статті на основі наукових джерел і досвіду викладання на юридичному факультеті окреслено педагогічні умови формування комунікативної компетентності майбутніх юристів. Увага акцентується, зокрема, на формуванні мотиваційно-ціннісного ставлення студентів до здійснення професійної комунікації під час занять із курсу «Українська мова за професійним спрямуванням», а також на збагаченні змісту спеціальних дисциплін інноваційними технологіями, що стимулює студентів до активної мовленнєвої діяльності.

Ключові слова: майбутній юрист, комунікативна компетентність, педагогічні умови, спеціальні дисципліни.

Насиленко Л. А. Педагогические условия формирования коммуникативной компетентности будущих юристов в процессе изучения специальных дисциплін.

В статье на основе научных работ и опыта преподавания на юридическом факультете представлены педагогические условия формирования коммуникативной компетентности будущих юристов. Внимание акцентируется в частности на формировании мотивационноценностного отношения студентов к совершению профессиональной коммуникации во время занятий по курсу «Украинский язык по профессиональному направлению», а также на усовершенствовании содержания специальных дисциплин инновационными технологиями, что стимулирует студентов к активной речевой деятельности.

Ключевые слова: будущий юрист, коммуникативная компетентность, педагогические условия, специальные дисциплины.

Nasilenko L. A. Pedagogical conditions of lawyers' communicative competence formation in the study of special subjects.

On the basis of scientific sources and teaching experience at the judicial faculty in the article are outlined pedagogical conditions of lawyers' communicative competence. Attention is paid in particular to the formation of motivational-value ratio of students to professional communication at the lessons of the course «Ukrainian language for professional purposes». Also the article enriches the contents of special disciplines with innovative technologies that stimulate students to speech activity.

Key words: lawyers', communicative competence, pedagogical conditions, special subjects.

Юрист у сучасному суспільстві - фахівець, здатний компетентно, у правовому полі розв'язувати соціальні конфлікти. Юридична професія пов'язана з підготовкою й оформленням значної кількості правових документів i вимагає вільного володіння юридичною термінологією, точних та чітких формулювань правових понять, логічних суджень, висновків, урахування багатозначності слів чи словосполучень. 